\title{
Synthesis of Fe Nanoparticles via One-Step Reduction Method
}

\author{
Hu Ping ${ }^{1,2}$, Kang Lu', $\quad$ Yang Jun $^{1}, \quad$ Yang Fan $^{1,2}, \quad$ Wang Kuaishe $^{1,2}$, Du Jinjing ${ }^{1}$, \\ Yang Zhanlin ${ }^{1}, \quad$ Cao Weicheng ${ }^{3}$, Liu Dongxin ${ }^{3}$
}

${ }^{1}$ School of Metallurgy Engineering, Xi' an University of Architecture and Technology, Xi' an 710055, China; ${ }^{2}$ State Local Joint Engineering Research Center for Functional Materials Processing, Xi'an University of Architecture and Technology, Xi'an 710055, China; ${ }^{3}$ Jinduicheng Molybdenum Co., Ltd, Xi'an 710077, China

\begin{abstract}
Fe nanoparticles were synthesized via a novel one-step reduction method. The excessive citric acid helps to obtain pure and high crystallinity $\alpha$-Fe at the appropriate temperature $\left(620^{\circ} \mathrm{C}\right)$. The Fe nanoparticles were characterized by the X-ray diffraction, transmission electron microscopy (TEM) and vibrating sample magnetometer (VSM). The morphological characterization indicates that the Fe nanoparticles present spherical shape with diameter of $30 \mathrm{~nm}$. The magnetization hysteresis loops reveal the high saturation magnetization $\left(M_{\mathrm{s}}=198.97 \mathrm{~A} \cdot \mathrm{m}^{2} / \mathrm{kg}\right)$ and the good ferromagnetic behavior of the magnetic materials. The one-step reduction method for nanoparticles synthesis has the advantages of controllable, short process, large-scale production, and will be an important method of producing nanoparticles.
\end{abstract}

Key words: Fe nanoparticles; one-step reduction; spherical shape; ferromagnetic behavior; magnetic materials

Iron nanoparticles have drawn much attention in recent years because they are promising candidates for numerous applications including catalysis ${ }^{[1]}$, the light absorption ${ }^{[2]}$, treatment ${ }^{[3,4]}$, magnetic media materials ${ }^{[5]}$, and medicine ${ }^{[6]}$. For example, magnetic iron nanoparticles as a carrier in combination with anti-tumor substances were located in the tumor area by the magnetic field, which can effectively control the distribution of medicine powders to achieve the targeted delivery of chemotherapy drugs. In addition, iron nanoparticles are important for waste water treatment and absorbing materials.

Synthesis of iron nanoparticles has been one of the most attractive challenges in the field of magnetic materials due to the large specific surface area and activity. The common methods for their preparation are high-energy ball milling ${ }^{[7]}$, sputtering ${ }^{[8]}$, DC arc plasma ${ }^{[9]}$, evaporation condensation ${ }^{[10]}$, ultrasonic chemical ${ }^{[11]}$, sol-gel ${ }^{[12]}$, and solvothermal ${ }^{[13]}$. Preparation of high-energy ball milling is easy to introduce impurities and leads to uneven distribution of the particles.
The products of sputtering and DC arc plasma method have high purity, but high energy consumption and high cost. Although the distribution of particles prepared by evaporation condensation or the ultrasonic chemical method is uniform, they demand stringent environmental conditions, and are difficult to apply in industry. A sol-gel method has controllable products, and good dispersion. In the present paper, we use a new method for preparing iron nanoparticles on the basis of the sol-gel method, and citric acid is used as a reducing agent with the diffusing reduction mechanism ${ }^{[14,15]}$. Our synthesis strategy has many advantages compared to other methods. Firstly, the synthesis approach is simple and easy to repeat. Secondly, the $\mathrm{Fe}$ nanoparticles are synthesized under moderate conditions which don't require any high temperature reaction. Finally, the product is much in the low-energy situation.

\section{Experiment}


The ferric nitrate $\left(\mathrm{Fe}\left(\mathrm{NO}_{3}\right)_{3} \cdot 9 \mathrm{H}_{2} \mathrm{O}\right)$ and citric acid $\left(\mathrm{C}_{6} \mathrm{H}_{8} \mathrm{O}_{7} \cdot \mathrm{H}_{2} \mathrm{O}\right)$ were used as raw materials. Firstly, the gel was prepared with the sol-gel method. $80 \mathrm{~g}$ ferric nitrate and $41.6 \mathrm{~g}$ citric acid were dissolved in $122 \mathrm{~mL}$ deionized water, and stirred with a magnetic stirrer at $17.5 \mathrm{r} / \mathrm{s}$. The gel was heated at $36{ }^{\circ} \mathrm{C}$, then stirred continuously for $30 \mathrm{~min}$, and aqueous ammonia was added dropwise to control $\mathrm{pH}$ at 7.10. The solution was heated to $60{ }^{\circ} \mathrm{C}$ and continuously stirred using magnetic agitation. After $4 \mathrm{~h}$, the $10 \mathrm{~mL}$ olefinic acid was added and the heating temperature was raised to $95{ }^{\circ} \mathrm{C}$. After continuously stirred for $4 \mathrm{~h}$, the products were washed three times with ethanol and then dried, milled. The powders performed in a protective atmosphere of argon gas were heated to $620{ }^{\circ} \mathrm{C}$, and held for $30 \mathrm{~min}$. Finally, the black powders were obtained, and treated with agate mortar by ultrasonic dispersing apparatus for $40 \mathrm{~min}$.

The crystalline structure of the black powders was verified by X-ray diffraction (D8, Buber, Germany) with $\mathrm{Cu}$ $\mathrm{K} \alpha$ radiation $(\lambda=0.15418 \mathrm{~nm}, 40 \mathrm{kV}, 30 \mathrm{~mA})$. The morphology of the black powders was characterized by transmission electron microscopy (M3000, Fischione, USA). The magnetic measurements were carried out by vibrating sample magnetometer (MPMS, Quantum Design, USA).

\section{Results and Discussion}

\subsection{Theoretical analysis}

In the one-step reduction of ferric nitrate to provide iron source, the citric acid is used as an organic chelating agent, and provides carbon source in the reducing atmosphere of carbon reduction. When the excessive citric acid is added, the high temperature could result in the breakage of $-\mathrm{C}$ bonds in citric acid, forming the single matter $\mathrm{C}$, which is used as a reducing agent to reduce the $\mathrm{Fe}_{2} \mathrm{O}_{3}$ to iron (Fig 1).

The X-ray diffraction (XRD) patterns (Fig.2) clearly show that all of the diffraction peaks could be indexed to $\mathrm{Fe}$ (JCPDS No. 87-0721). As it is observed in this figure, the particles have typical bcc structure of $\alpha$-Fe phase with the peak of (110), (200), (211) at $2 \theta \approx 44^{\circ}, 65^{\circ}, 82^{\circ}$, respectively. It indicates that the product consists of pure Fe and high crystallinity could be detected.

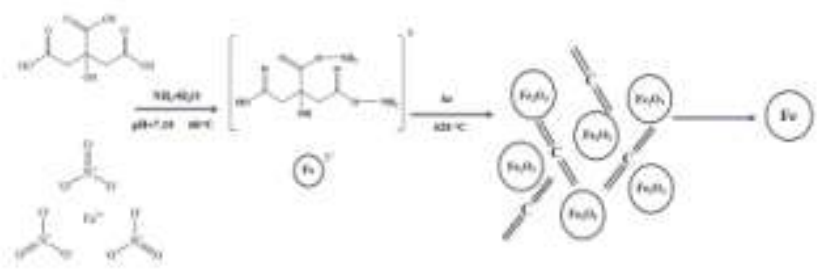

Fig.1 Schematic synthesis of iron nanoparticles via one-step reduction method

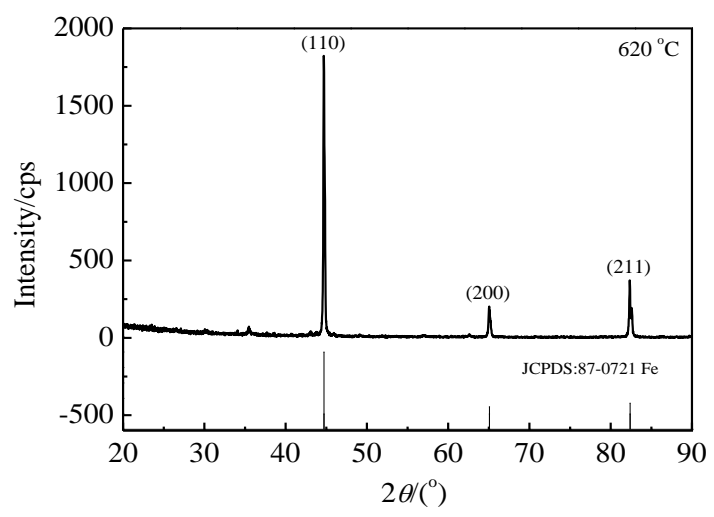

Fig.2 XRD patterns of final products

\subsection{TEM analysis of the reaction product}

Fig.3a and $3 b$ show the powders with nearly spherical shape and the average diameters of $30 \mathrm{~nm}$. Fig.3c and $3 \mathrm{~d}$ exhibit a few nanoparticles which are agglomerated because of their high surface energy. The TEM images of the nanoparticles indicate that the nanoparticles are monodisperse and their size can be controlled in the range of $20 \sim 40 \mathrm{~nm}$.

\subsection{Magnetic properties}

The magnetization in Fig.4 shows the magnetization hysteresis loops of the Fe nanoparticles. It is clear that synthesized Fe nanoparticles exhibit good ferromagnetic behavior. The saturation magnetization $M_{\mathrm{s}}=198.97 \mathrm{~A} \cdot \mathrm{m}^{2} / \mathrm{kg}$ (upper-left inset of Fig.4) is superior to that of the bulk

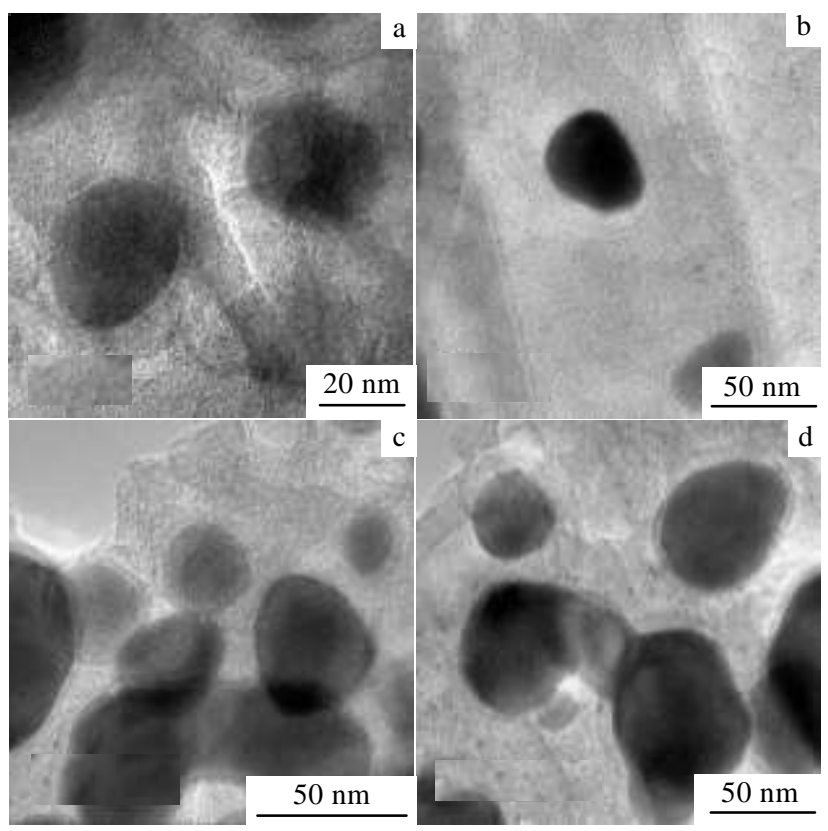

Fig.3 TEM images of $\mathrm{Fe}$ nanoparticles (a, b) and a few aggregated nanoparticles (c, d) 


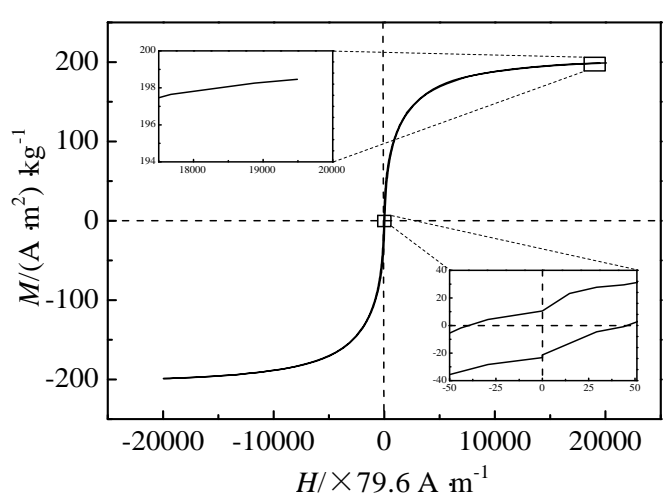

Fig.4 Magnetic hysteresis loop of the synthesized $\mathrm{Fe}$ nanoparticles

$\mathrm{Fe}_{3} \mathrm{O}_{4}, M_{\mathrm{s}}=92 \mathrm{~A} \cdot \mathrm{m}^{2} / \mathrm{kg}$. Moreover, they can be used as MRI contrast performance and drug delivery in the medical field because of the better microstructure, crystallinity and dispersibility. In the future, for having good magnetic response, Fe nanoparticle will be made a profound and specific material.

\section{Conclusion}

1) Pure Fe nanoparticles have been synthesized via a one-step reduction method which is on the basis of the sol-gel method, when the molar ration of ferric nitrate and citric acid molar ratio is $1: 1$, and the reduction temperature is $620^{\circ} \mathrm{C}$.

2) The nanoparticles show nearly spherical shape with the diameter ranging from $20 \mathrm{~nm}$ to $40 \mathrm{~nm}$. The magnetic measurement shows the ferromagnetic behavior of the product.
3) The method is simple, portable and other metal oxide nanoparticles can be also synthesized.

\section{References}

1 Li F, Cumaraswamy V, Kishore K M. Colloids and Surfaces A: Physicochemical and Engineering Aspects[J], 2003, 223: 103

2 Dadashi S, Poursalehi R, Delavari H. Procedia Materials Science [J], 2015, 11: 722

3 Li Z J, Wang J, Yuan L Y et al. Journal of Hazardous Materials[J], 2015, 290: 26

4 Xin J, Tang F L, Shao H B et al. Water Research[J], 2016, 88: 199

5 Candance T S, Charles J O. Nanostructured Materials[J], 1999, 12: 183

6 Saboktakin M R, Tabatabaie R M, Maharramov A et al. Carbohydrate Polymers[J], 2010, 80: 695

7 Carvalho J F, Medeiros S N, Morales M A et al. Applied Surface Science[J], 2013, 275: 84

8 Jiménez-Villacorta F, Muñoz-Martín A, Prieto C. Nuclear Instruments and Methods in Physics Research Section B: Beam Interactions with Materials and Atoms[J], 2005, 238: 340

9 Zhang F, Cui L, Lin K et al. J Alloy Compd[J], 2013, 553: 367

10 Lee D W, Yu J H, Jang T. J Mater Sci Technol[J], 2010, 26: 367

11 Hassanjani-Roshan A, Vaezi M R, Shokuhfar A et al. Particuology[J], 2011, 9: 95

12 Azam Kanwal Akhtar M, Riaz S, Naseem S. Materials Today: Proceedings[J], 2015, 2: 5700

13 Hou Y L, Gao S. J Alloy Compd[J], 2004, 365: 112

14 Yu L Q, Dong K T, Yang C et al. Mater Lett[J], 2014, 132: 4

15 Yu L, Yang C, Hou Y. Nanoscale[J], 2014, 6: 10638

\section{一步还原法制备纳米铁粉}

胡 平 ${ }^{1,2}$, 康 路 $^{1}$, 杨 军 $^{1}$, 杨 帆 $^{1,2}$, 王快社 ${ }^{1,2}$, 杜金晶 ${ }^{1}$, 杨占林 ${ }^{1}$, 曹维成 ${ }^{3}$, 刘东新 ${ }^{3}$

(1. 西安建筑科技大学 治金工程学院, 陕西 西安 710055)

(2. 西安建筑科技大学 功能材料加工国家地方联合工程研究中心, 陕西 西安 710055)

(3. 金堆城钼业股份有限公司，陕西 西安 710077)

摘 要: 采用一种新方法——步还原法制备了纳米铁粉颗粒。过量的柠檬酸在 $620{ }^{\circ} \mathrm{C}$ 有助于形成纯相、结晶高的 $\alpha$ - $\mathrm{Fe}$ 。纳米铁粉被 $X$ 射线衍射(XRD)、透射电子显微镜(TEM)、振动样品磁强计(VSM)进行了表征, 形貌观察表明产物形成了粒径在 $30 \mathrm{~nm}$ 左右的近球形 的纳米颗粒。磁滞回线说明了纳米铁颗粒的饱和磁化强度为 $198.97 \mathrm{~A} \cdot \mathrm{m}^{2} / \mathrm{kg}$, 作为磁性材料具有很好的铁磁性能。一步还原法生产的 颗粒粒径分布窄、可控、流程短, 可用于大规模生产。

关键词: 纳米铁; 一步还原法; 球形; 铁磁行为; 磁性材料

作者简介: 胡 平, 男, 1985 年生, 博士, 副教授, 西安建筑科技大学冶金工程学院, 陕西 西安 710055, 电话: 029-82202923, E-mail: huping1985@126.com 